\title{
ZUR TONKUNST.
}





\section{ZUR TONKUNST.}

A B H ANDLUNGEN

YON

ERNST 0TTO LINDNER.

BERLIN,

I. GUT TEN T $\Lambda$ G.

1864 . 
